\title{
OPTIMALISASI MEDIA SOSIAL SEBAGAI SARANA PROMOSI WISATA PANTAI ASMARA
}

\author{
Leila Ariyani Sofia, Achmad Syamsu Hidayat, dan Muhammad Adnan Zain \\ Fakultas Perikanan dan Kelautan, Program Studi Agrobisnis Perikanan \\ Universitas Lambung Mangkurat \\ E-mail : leila.ariyani@ulm.ac.id
}

\begin{abstract}
ABSTRAK
Pantai Asmara, Desa Muara Asam-asam Kabupaten Tanah Laut mulai dikembangkan sebagai obyek wisata alam sejak tahun 2016 oleh Pokdarwis Pantai Asmara. Pantai Asmara dengan segala keindahannya terus dibenahi dan dilengkapi segala fasilitasnya untuk lebih meningkatkan minat wsiatawan untuk berkunjung. Namun, pengembangan wisata Pantai Asmara masih memiliki keterbatasan pada aspek promosi, dimana kegiatan promosi belum terkelola dengan baik intensitas promosi yang masih sedikit. Oleh sebab itu, informasi yang diperoleh wisatawan cukup terbatas dan cenderung parsial. Tujuan PKM ini adalah (1) memberikan penyuluhan tentang jenis materi (konten) promosi, tata letak, dan akun media sosial; (2) memberikan pelatihan teknis penyusunan konten promosi berbasis media sosial. Metode kegiatan PKM yang diterapkan adalah (1) penyuluhan dan diskusi; (2) pelatihan dan pendampingan; dan (3) evaluasi kegiatan. Hasil kegiatan menunjukkan bahwa penyuluhan telah memberikan perubahan sikap dan pengetahuan khalayak sasaran (kelompok mitra) terhadap pemanfaatan media sosial sebagai sarana promosi wisata Pantai Asmara dari kurang menjadi cukup banyak mengetahui. Proses adopsi dan difusi iptek promosi produk jasa wisata oleh anggota kelompok mitra ke anggota masyarakat lainnya sudah tergolong cukup (bernilai 60 - 80 dengan rata-rata 68). Pokdarwis Pantai Asmara telah mampu mempersiapkan dan menyusun konten akun promosi produk jasa dalam format sederhana sesuai pengetahuan dan kemampuan kelompok.
\end{abstract}

Kata Kunci: wisata, pantai, media sosial, akun, promosi

\section{PENDAHULUAN}

Wisata bahari secara global di tahun 1993 mampu menghasilkan devisa sekitar 6-7\% dari total pendapatan kotor dunia (WTO, 2000). Kontinuitas perkembangan wisata bahari akan berimplikasi pada bidang usaha wisata lainnya, seperti perhotelan, jasa rekreasi, biro perjalanan, dan restoran di sekitar kawasan wisata
(Aryanto dan Mardjuka, 2005). Pantai Asmara merupakan kawasan pantai yang berada di Desa Muara Asam-asam Kecamatan Jorong Kabupaten Tanah Laut Kalimantan Selatan. Perairan pantai ini berarus cukup tenang, terdapat hamparan pasir putih di sepanjang pantai, dan lingkungan yang masih tergolong bersih sehingga sangat 
potensial untuk dikembangkan lebih lanjut.

Di sisi lain, Desa Muara Asamasam memiliki luas wilayah $\pm 10 \mathrm{~km}^{2}$ dan berada di pinggiran Laut Jawa yang membentang sepanjang desa dengan jumlah penduduk mencapai 2.615 jiwa (1.376 jiwa laki-laki dan 1.239 jiwa perempuan) dan kepadatan penduduk mencapai 261 jiwa $/ \mathrm{km}^{2}$ (Kecamatan Jorong Dalam Angka, 2018). Hampir $70 \%$ masyarakat desa ini bermata pencaharian sebagai nelayan. Desa Muara Asam-asam tergolong sebagai kawasan miskin karena secara fisik masih banyak rumah masyarakat yang menggunakan atap daun, lantai kayu, dan berdinding papan tipis karena seringnya masyarat berpindah tempat (BKKBN Kalsel, 2017).

Sumberdaya Pantai Asmara yang potensial tersebut kemudian dimanfaat dan dikelola oleh Kelompok Pemuda Sadar Wisata (pokdarwis) Pantai Asmara sebagai obyek wisata dan dibuka secara resmi pada bulan Januari 2016. Pengembangan obyek wisata pantai ini diharapkan akan menjadi alternatif sumber perekonomian masyarakat desa. Pantai ini ramai dikunjungi wisatawan terutama pada akhir pekan dan musim libur.
Pengunjung adalah warga lokal, berasal dari Banjarmasin dan sekitarnya, serta dari luar Kalimantan Selatan. Pengelola juga telah menyediakan berbagai wahana rekreasi air dan pantai, beberapa spot foto yang cukup menarik dan instragramable, serta fasilitas penunjang, seperti penginapan, warung makan, toilet, mushalla, dan lainnya.

Namun, hingga saat ini informasi tentang keberadaan Pantai Asmara sebagian besar didapat calon pengunjung dari informasi lisan maupun beberapa tulisan singkat dari para wisatawan yang telah mengunjunginya. Padahal informasi lengkap dan menyeluruh dari suatu komoditi melalui promosi merupakan salah satu faktor utama untuk meningkatkan minat konsumen terhadap suatu produk (Michael Ray dalam Morissan, 2010; Akhter, et al. 2014), dan mampu mempengaruhi keputusan pem-belian (Cravens, 2013). Begitu pula dengan industri pariwisata sebagai suatu bisnis berbasis jasa membutuhkan promosi yang intensif sebagai faktor utama untuk memajukan suatu obyek wisata.

Media sosial adalah sebuah revolusi media yang memberikan konsumen kekuatan penuh dalam 
mendapatkan sebuah informasi dan menyampaikan sebuah informasi (Kerpen, 2011). Promosi produk/jasa dengan media sosial secara intensif akan mendukung brand awareness dari sebuah produk (Ebeid, 2014; Schivinski \& Dabrowski, 2015).

Pemasaran produk/jasa melalui media sosial telah menjadi cara terbaik untuk memperluas pasar ataupun pelanggan. Hal ini disebabkan media sosial memiliki kelebihan peran dan fungsi dibandingkan media konvesional, yaitu (a) lebih sederhana, (b) membangun hubungan, jangkauan global, dan (d) terukur (Prasetyo, 2018).

Salah satu bentuk media promosi yang dapat disajikan adalah akun. Akun mampu menyebarkan informasi produk kepada target pasar potensial dan memberikan citra positif pengunjung terhadap produk, serta memberikan ruang interaksi antara produsen dengan pelanggan, serta mendatangkan pelanggan baru (Hidayatullah, 2013). Freelance blogger juga salah satu agen yang berperan aktif dalam membantu untuk mempromosikan pariwisata melalui internet dan media sosial (Suryadi \&
Yusrizal, 2016; Adiyanto \& Supriatna, 2018).

Tujuan PKM ini adalah (1) memberikan penyuluhan tentang jenis materi (konten) promosi, tata letak, dan akun media sosial; (2) memberikan pelatihan teknis penyusunan konten promosi berbasis media sosial.

\section{METODE PELAKSANAAN}

Kegiatan PKM dilaksanakan di Desa Muara Asam-asam Kecamatan Jorong Kabupaten Tanah Laut, Kalimantan Selatan pada Agustus sampai Oktober 2019.

Metode pendekatan yang digunakan dalam kegiatan PKM ini adalah (a) penyuluhan dan diskusi; (2) pelatihan, demonstrasi, dan pendampingan; dan (4) evaluasi kegiatan. Penyuluhan dilaksanakan dalam bentuk kunjungan dan pertemuan dengan kelompok mitra untuk memberikan penjelasan teori secara lisan dengan bantuan multimedia, dan materi teknologi tercetak (folder) (Wahyudi dan Gunari, 2013; Patekkai, 2013).

Demonstrasi implementasi penyusunan konten promosi berbasis media sosial dilakukan oleh tim Pengabdi dan dipraktikkan kembali oleh kelompok mitra, yaitu pemilihan jenis materi (konten) promosi, tata letak (lay out), 
dan akun media promosi. Selama pelaksanaan semua tahapan kegiatan mulai dari penyuluhan (penjelasan teori) hingga demonstrasi, anggota kelompok mitra selalu diberi pelatihan dan pendampingan secara bertahap.

Data primer yang telah dikumpulkan dianalisis secara deskriptif. Sedangkan evaluasi keberhasilan untuk jangka pendek dilakukan dengan membandingkan tingkat pengetahuan, keterampilan, dan motivasi anggota kelompok mitra dalam menerapkan teknologi. Pengujian dilakukan dengan membandingkan tingkat pengetahuan sebelum dan sesudah kegiatan berlangsung perbandingan dilakukan dengan menggunakan uji dua pihak (Sudjana, 1984), dengan persamaan:

$$
t \text { hitung }=\frac{y-x}{s \sqrt{1 / n 1+1 / n 2}}
$$

Kriteria pengujian :

Terima Ho, jika $\mathrm{t}_{1}-1 / 2 \mathrm{a}<\mathrm{t}<\mathrm{t}_{1}-1 / 2 \mathrm{a}$

Tolak Ho, untuk harga-harga lainnya.

Evaluasi keberhasilan jangka panjang adalah melihat jumlah anggota kelompok mitra mampu mengelola usaha berdasarkan teknik-teknik manajemen usaha yang baik, serta pemasaran produk melalui jaringan pemasaran yang efisien yang dapat menjangkau pasar lokal dan luar daerah, terjadinya adopsi dan difusi promosi produk oleh anggota kelompok mitra ke anggota masyarakat lainnya. Pengukuran keberhasilan jangka panjang menggunakan kriteria penilaian sebagai berikut:

(a) Jika nilai evaluasi berkisar antara $80-100=$ sangat baik

(b) Jika nilai evaluasi berkisar antara $70-79=$ baik

(c) Jika nilai evaluasi berkisar antara $56-69=$ cukup

(d) Jika nilai evaluasi kurang dari atau sama dengan $55=$ kurang

\section{HASIL DAN PEMBAHASAN}

Keadaan Umum Pengelolaan Wisata Pantai Asmara

Objek wisata Pantai Asmara merupakan pantai yang terbentuk dari aktivitas warga setempat yang peduli dengan lingkungan pantai. Pengelolaan pantai ini dilaksanakan oleh beberapa kelompok swadaya masyarakat dan para pemuda yaitu Kelompok Sadar Wisata (Pokdarwis) Pantai Asmara, Karang Taruna Bina Asmara, Karang Taruna Merpati Putih Asmara, serta Kelompok PKK Asmara (ibu-ibu dan remaja putri). 


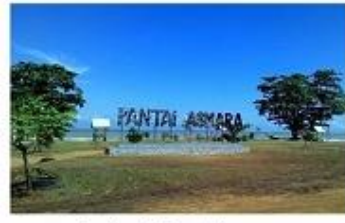

Lamomark Pantai Asmara

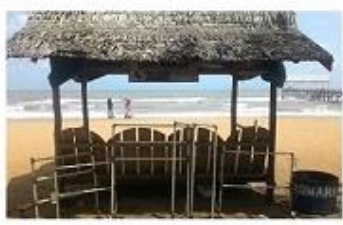

Greebo untuk beristirahant

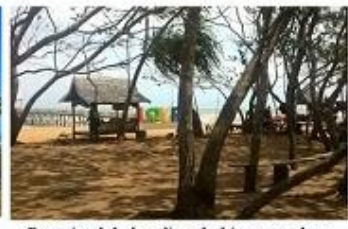

Pantai teduh dan ditumbulhi cemara laut

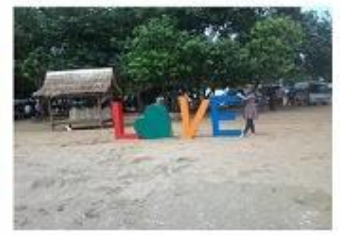

Fenture yang menarik
Gambar 1. Sarana dan prasarana wisata Pantai Asmara

Sejumlah kelompok swadaya masyarakat tersebut bersama-sama dan saling bersinergi dalam menjaga kebersihan, keamanan, serta ketersediaan sarana dan prasarana dengan tujuan untuk memberikan kenyamanan maksimal bagi para wisatawan sehingga betah di lokasi wisata dan diharapkan akan kembali lagi berkunjung ke tempat tersebut. Sarana dan prasarana yang telah tersedia antara lain: penanda (landmark) lokasi wisata, warung/kios makanan dan minuman, pos penjagaan, toilet dan kamar mandi, taman bermain anak, gazebo dan penginapan, serta fasilitas permainan air lainnya. Untuk sarana penginapan telah tersedia penginapan yang dikelola pihak swasta yaitu Villa Asmara dengan jumlah kamar sebanyak 10 unit dengan fasilitas berupa tempat tidur dan 6 kamar dilengkapi AC dan sisanya dilengkapi kipas angin, serta terdapat pula kafe dan kolam pemancingan. Sedangkan sarana penginapan yang dikelola warga lokal tersedia 130 kamar dengan ukuran rata-rata 2 × $3 \mathrm{~m}^{2}$ yang dilengkapi tempat tidur sederhana dan kipas angin. Pengelolaan pantai Asmara telah diatur melalui peraturan desa (perdes), diantaranya adanya kontribusi pengelola pantai untuk kas desa.
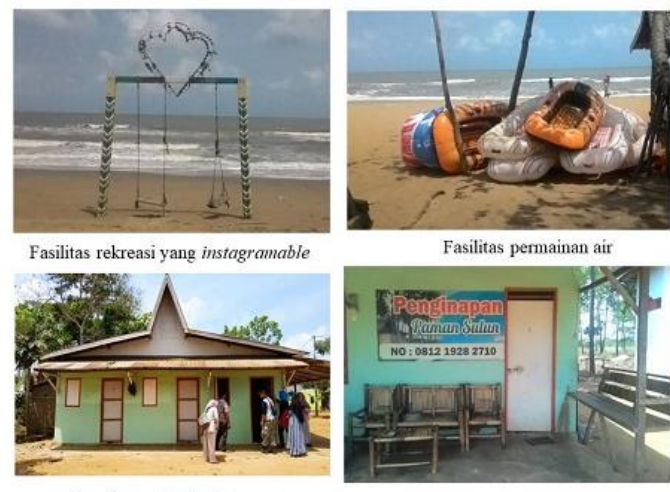

Penginapan bagi wisatawan

Penginapan milik warga lokal

Gambar 2. Fasilitas bagi para

wisatawan

Jumlah pengunjung wisata pantai Asmara menurut informasi pihak pengelola pada akhir pekan rata-rata mencapai 100 orang. Sementara, puncak kunjungan tahunan biasanya terjadi dalam sepekan liburan tahun baru, perayaan pesta pantai "Mappanretase" dan setelah perayaan hari raya Idul Fitri, dimana jumlah pengunjung setiap harinya mencapai $300-500$ orang. 
Penyuluhan dan Pelatihan bagi

\section{Pokdarwis Pantai Asmara}

Kegiatan PKM yang telah dilaksanakan berupa kunjungan dan pertemuan dengan kelompok mitra dengan tujuan memberikan penjelasan tentang alternatif promosi melalui pemanfaatan media sosial yang tersedia sebagai salah satu upaya pemasaran obyek wisata Pantai Asmara. Untuk lebih memudahkan pemahaman peserta suluh maka penyuluhan dilengkapi pula dengan materi yang disajikan dalam bentuk folder. Selain itu, pada kegiatan ini juga diadakan sesi tanya jawab dengan tujuan memberikan kesempatan bagi peserta suluh untuk bertanya terkait materi suluh ataupun menyampaikan beberapa permasalahan yang mereka alami.

Kegiatan penyuluhan dihadiri oleh 20 orang peserta suluh yang terdiri dari 7 orang anggota pokdarwis Pantai Asmara, 4 orang anggota Karang Taruna Bina Asmara, 2 orang anggota PKK dan 7 orang pengelola usaha di pantai Asmara. Pada kegiatan ini terlihat bahwa sasaran suluh cukup antusias menyimak materi yang disampaikan oleh tim pengabdi karena menurut mereka memang dapat memberikan manfaat yang berarti bagi pengembangan wisata pantai Asmara dan peningkatan ekonomi masyarakat lokal.

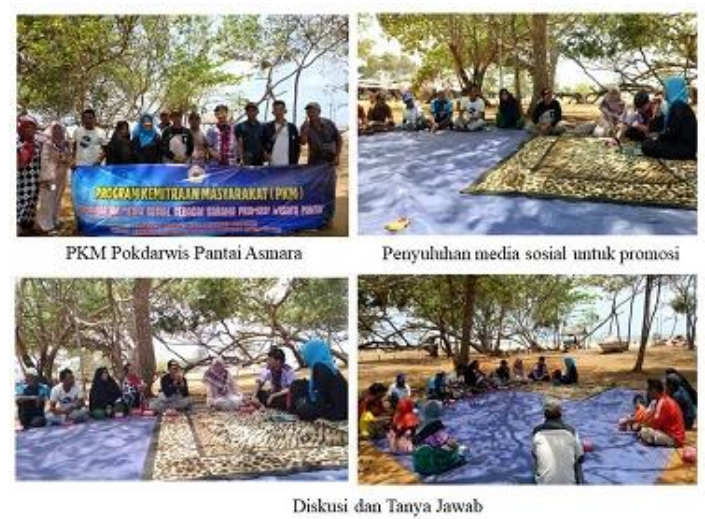

Gambar 3. Pelaksanaan Penyuluhan dan Pelatihan kepada Kelompok Mitra

Pokdarwis menyadari bahwa selama ini promosi yang dilakukan tidak instensif, bahkan cenderung meng-andalkan pihak pengelola desa ataupun informasi verbal yang dilakukan pengunjung saja. Pada kegiatan PKM ini juga dilakukan demonstrasi penyusunan konten promosi berbasis media sosial meliputi berbagai jenis materi promosi, tata letak (lay out), dan akun media promosi. 


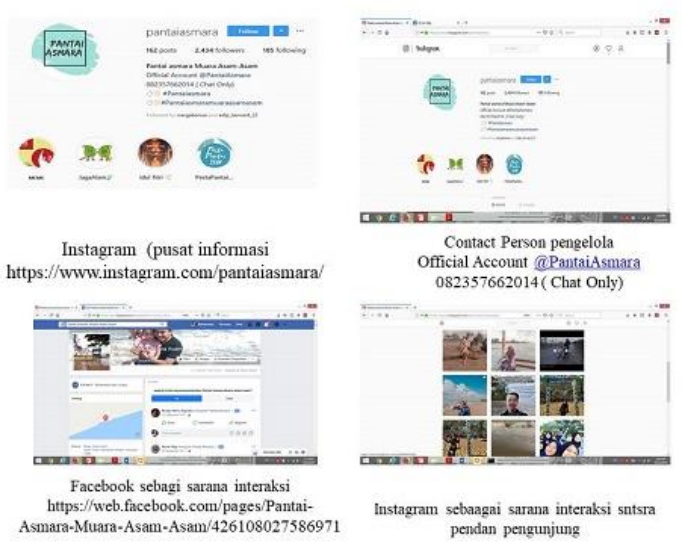

Gambar 4. Akun media promosi

wisata Pantai Asmara

Selama pelaksanaan berbagai tahapan kegiatan dari penjelasan teori hingga penyusunan konten media sosial dan pembuatan akun, anggota kelompok mitra selalu diberi pelatihan bertahap dan pendampingan oleh tim pengabdi. Dengan demikian, kelompok mitra dapat mandiri mempersiapkan dan menyusun konten akun promosi produk jasanya yang dimulai dari bentuk yang sederhana sesuai pengetahuan dan kemampuan kelompok.

Hasil evaluasi awal dan evaluasi akhir kemudian dianalisis dengan menggunakan analisis uji dua pihak sehingga akan diketahui perubahan sikap dan pengetahuan khalayak sasaran. Pada evaluasi awal diketahui bahwa nilai rata-rata pengetahuan kelompok mitra terhadap media sosial dan pemanfaatannya adalah 12,3. Setelah dilakukan penyuluhan terjadi peningkatan pengetahuan kelompok mitra dengan nilai rata-rata sebesar 15,25. Hasil analisis juga menunjukkan terjadi penurunan variasi nilai jawaban sasaran suluh dari 44,32 menjadi 13,99 (Tabel 1). Dengan demikian, adanya kegiatan penyuluhan telah memberikan pengaruh pada penurunan variasi pengetahuan sasaran suluh ke arah tingkat pengetahuan yang lebih merata (sama).

Hasil pengujian perbedaan tingkat pengetahuan kelompok mitra sebelum dan sesudah kegiatan penyuluhan diperoleh nilai $\mathrm{t}$ hitung sebesar 3,75 (lebih dari t tabel 2,09), berarti telah terjadi perubahan sikap dan pengetahuan khalayak sasaran (kelompok mitra) dari yang kurang mengetahui menjadi cukup banyak mengetahui tentang pemanfaatan media sosial sebagai sarana promosi wisata Pantai Asmara.

Tabel 1. Hasil analisis t-Test: Paired Two Sample for Means

\begin{tabular}{|l|r|r|}
\hline & Sebelum & Sesudah \\
\hline Mean & 12,3 & 15,25 \\
\hline Variance & 44,32632 & 13,98684 \\
\hline Observations & 20 & 20 \\
\hline Pearson Correlation & 0,922656 & \\
\hline Hypothesized Mean Difference & 0 & \\
\hline df & 19 & \\
\hline$t$ Stat & $-3,75168$ & \\
\hline$P(T<=t)$ one-tail & 0,000675 & \\
\hline$t$ Critical one-tail & 1,729133 & \\
\hline P $(T<=t)$ two-tail & 0,001351 & \\
\hline$t$ Critical two-tail & 2,093024 & \\
\hline
\end{tabular}




\section{Pembahasan}

Tingkat pengetahuan khalayak sasaran tentang penerapan teknologi media sosial sebagai sarana promosi obyek wisata Pantai Asmara dapat dikelompokkan menjadi:

1) Sekitar $50 \%$ sasaran suluh telah mengetahui beberapa jenis media sosial. Jenis media sosial yang banyak dikenal sasaran suluh adalah facebook, whatapps, youtube, dan instagram.

2) Masih ada sekitar $50 \%$ sasaran suluh yang tidak dapat menuliskan nama-nama media sosial yang pernah digunakan, $10 \%$ dapat menuliskan 1-2 jenis media sosial, dan $40 \%$ dapat menuliskan $\geq 3$ jenis media sosial.

3) Intensitas penggunaan media sosial oleh sasaran suluh terdiri dari $40 \%$ tidak pernah menggunakan media sosial, 15\% menggunakan 1 -2 kali sehari, $15 \%$ menggunakan 3-5 kali sehari, dan $30 \%$ termasuk sangat sering menggunakan.media sosial.

4) Sekitar $45 \%$ sasaran suluh menyatakan fungsi media sosial adalah untuk menggali dan menyebarkan informasi, $35 \%$ menyatakan dengan media sosial mereka dapat melihat informasi baru, dan $20 \%$ sisanya menyatakan dapat melihat apapun.

5) Sekitar $80 \%$ sasaran suluh menyatakan perangkat yang digunakan untuk membuka/ memanfaatkan media sosial adalah ponsel milik sendiri.

Sementara, hasil evaluasi keberhasilan jangka panjang berdasarkan kemampuan kelompok mitra mengelola usaha dengan teknikteknik manajemen usaha yang baik serta pemasaran produk melalui jaringan pemasaran yang efisien yang dapat menjangkau pasar lokal dan luar daerah, terjadinya adopsi dan difusi promosi produk oleh anggota kelompok mitra ke anggota masyarakat lainnya dimana nilai evaluasi penilaian berkisar antara 60 - 80 dengan rata-rata nilai 68 , berarti masih berada pada kriteria cukup.

Beberapa informasi yang dibutuhkan calon wisatawan seperti ketersediaan dan jenis sarana prasarana penginapan selama ini tidak dapat terinformasikan secara luas karena hanya didapatkan apabila calon wisatawan menghubungi pengelola penginapan yang mereka ketahui saja. Selain itu, informasi kepadatan pengunjung adalah sangat penting bagi calon wisatawan dalam menyusun 
jadwal kunjungan sehingga mereka benar-benar dapat menikmati liburannya, serta bagi pengelola wisata akan dapat memperkirakan jumlah dan jenis sarana dan prasarana yang harus mereka sediakan sehingga mampu memberikan pelayanan terbaik bagi wisatawan. Dengan adanya akun media sosial pokdarwis diharapkan berbagai informasi tentang wisata pantai Asmara dapat tersaji dengan lengkap.

Faktor pendorong dalam kegiatan ini adalah besarnya kemauan anggota kelompok untuk mengembangkan usaha dengan meningkatkan kualitas dan kuantitas jasa layanan dan promosi. Umumnya anggota kelompok telah mengetahui jenis-jenis media sosial tetapi belum memanfaatkannya sebagai sarana promosi wisata yang mereka kelola. Sedangkan faktor penghambat dalam mencapai tujuan penyuluhan adalah sebagian anggota kelompok masih berpendidikan dasar dan menengah sehingga sangat diperlukan peranan kelompok untuk membantu dan membina mereka agar mampu mandiri.

Proses adopsi seseorang sampai pada tahapan yang meyakinkan dimana mereka mau menerapkan materi penyuluhan (bahan-bahan tuntunan/ bimbingan) akan melalui beberapa tahapan. Pentahapan tersebut sebagai berikut:

1) Mengetahui dan menyadari materi yang disampaikan

2) Penaruhan minat terhadap materi yang disampaikan

3) Penilaian terhadap materi yang disampaikan

4) Melakukan percobaan terhadap materi yang disampaikan

5) Penerapan/adopsi terhadap materi yang disampaikan

Berdasarkan hasil evaluasi terhadap materi yang disampaikan dapat diketahui tahapan penerimaan khalayak sasaran berada pada tahapan penaruhan minat yaitu dicirikan dengan perubahan sikap dimana khalayak sasaran telah menaruh minat terhadap pengelolaan informasi wisata pantai Asmara yang terintegrasi antar berbagai jenis pengelolaan dan usaha yang dikembangkan masyarakat sehingga akan berdampak terhadap perluasan pangsa pasar, tidak hanya menunggu pemesanan tetapi mulai mempromosikan objek wisata ke segmen pasar lainnya.

\section{KESIMPULAN}

Penyuluhan telah memberikan per-ubahan sikap dan pengetahuan 
khalayak sasaran (kelompok mitra) terhadap pemanfaatan media sosial sebagai sarana promosi wisata Pantai Asmara dari kurang menjadi cukup banyak mengetahui. Proses adopsi dan difusi iptek promosi produk jasa wisata oleh anggota kelompok mitra ke anggota masyarakat lainnya sudah tergolong cukup (bernilai $60-80$ dengan rata-rata 68). Pokdarwis Pantai Asmara telah mampu mempersiapkan dan menyusun konten akun promosi produk jasa dalam format sederhana sesuai pengetahuan dan kemampuan kelompok.

\section{UCAPAN TERIMA KASIH}

Kami mengucapkan terima kasih yang sebesar-besarnya kepada Fakultas Perikanan dan Kelautan Universitas Lambung Mangkurat selaku penyandang dana kegiatan (PNBP FPK sesuai DIPA Universitas Lambung Mangkurat

No.B/02/UN8.1.27/PM.01.01/2019

Tanggal 20 Agustus 2019), Kepala Desa Pantai Asmara, dan Pokdarwis Pantai Asmara yang telah bersedia bekerjasama dan memberikan informasi yang kami butuhkan.

\section{DAFTAR PUSTAKA}

Adiyanto, Y dan Supriatna, Y. 2018. Analisis strategi promosi dalam pengembangan pariwisata di Kabupaten Lebak Banten. Jurnal Sains Manajemen. 4 (2): 83 - 93.

Akhter, S., Rizwan, M., Shujaat, S., \& Durrani, Z. 2014. The Impact of Retail Shoes Sales Promotional Activities on Ladies' Purchase Intentions. Journal of Public Administration and Governance. 4(2): 166-178.

Aryanto, R. dan Mardjuka, M.Y. 2005. Valuasi ekonomi dengan travel cost method pada obyek ekowisata pesisir. Jurnal Ilmiah Pariwisata. 10(1): 58- 76.

Cravens, D. W. 2013. Strategic marketing $10^{\text {th }}$ ed. $658.802 \mathrm{C} 898$ 2013.

Ebeid, A. Y. 2014. Distribution intensity, advertising, monetary promotion, and customer based brand equity: an applied study in Egypt. International Journal of Marketing Studies. 6(4): 113-122. https://doi.org/10.5539/ijms.v6n4 p113.

Hidayatullah, N. 2013. Promosi penjualan melalui jejaring sosial (studi deskriptif kualitatif promosi penjualan melalui jejaring sosial twitter pada "Coffee House Ulee Kareng").

https://jurnal.usu.ac.id/index.php/f low/article/view/ 12862. Diakses tanggal 1 Juli 2019.

Kerpen, D. 2011. likeable Social Media: How to delight Your Customer, Create an Irresistible Brand, And Be Generally Amazing on Facebook, McgrawHill. Kindleedition. 
Morissan, M.A. 2010. Psikologi Komunikasi. Ghalia Indonesia. Bogor.

Patekkai, Muh. 2013. Produksi Media Penyuluhan Audio Visual. Bimbingan Teknis Pembuatan Media Penyuluhan Perikanan tanggal 19 Desember 2013 di Jakarta. Pusat Penyuluhan Kelautan dan Perikanan Badan Pengembangan Sumber Daya Kelautan dan Perikanan Kementerian Kelautan dan Perikanan. Jakarta. pp.12.

Prasetyo, H. 2018. Media Sosial sebagai Media Promosi Masa Kini.

https://www.kompasiana.com/had iprasetyo9292/5b4a38eef133440e 266eb1e4/media-sosial-sebagaimedia-promosi-masa-kini? page $=2$ (15 Juli 2018). Diakses tanggal 1 Juli 2019.

Schivinski, B., \& Dabrowski, D. 2015. The impact of brand communication on brand equity through facebook. Journal of Research in Interactive Marketing. 9(1): 31-53.

Sudjana, M. 1984. Metode Statistika. Penerbit Tarsito. Bandung. pp. 96.

Suryadi, M.I \& Yusrizal, F. 2016. Pelaksanaan promosi melalui media sosial pada objek wisata dakwah Okura Kecamatan Rumbai Pesisir Kota Pekanbaru. JOM FISIP. 3 (2): 1 - 15.

Wahyudi, A. dan I. Gunari. 2013. Bimbingan Teknis Media Tercetak. Bimbingan Teknis Pembuatan Media Penyuluhan Perikanan tanggal 19 Desember 2013 di Jakarta. Pusat Penyuluhan Kelautan dan Perikanan Badan Pengembangan Sumber Daya Kelautan dan Perikanan, KKP. Jakarta. pp.3.

WTO (World Tourism Organization). 2000. Tourism Trends. Madrid. 